The History of Sexually Transmitted Diseases. No 7 in a series edited by Milton Lewis and Michael Waugh.

\title{
Sexually transmitted diseases in Canada, 1800-1992
}

\author{
H MacDougall
}

\begin{abstract}
The history of sexually transmitted diseases in Canada from 1800 to the present reflects the changing views and values of citizens, medical experts, politicians and bureaucrats. During the colonial period, the military devoted attention to the problem but strict moral codes and social conventions prevented public discussion. Although middle class reformers began to pressure the federal government for funding and direction after 1900, World War I was the catalyst for involvement. Health education through a voluntary group and federalprovincial cost-shared funding for treatment facilities across Canada were introduced to control STDs. Public perception of STD patients as marginalised or deviant limited the impact of these efforts. Social changes during the 1960s, new STDs appearing in the 1970s and the AIDS epidemic of the 1980 s have redirected the STD campaign to focus on high risk groups and prevention rather than the moralistic curative efforts of the past.
\end{abstract}

(Genitourin Med 1994;70:56-63)

\section{Introduction}

From a presumed outbreak of 'sibbens' in the 1770 s to the AIDS epidemic of the present, Canadians and their governments have tried to develop policies to control and prevent the spread of STDs. Drawing on slowly evolving medical knowledge and the legislative model provided by Great Britain, other Dominions and the United States, Canadians have adapted these external developments to the realities of their political, social and economic systems. As the country evolved from a scattered collection of resource-dependent British colonies to a modern industrialised nation of 27 million, it was transformed from a series of rural pioneer communities into an urban, multicultural society.

By examining the attitudes and values which have shaped policy formation, assessing the process by which STD policies have been implemented within the Canadian federal system and evaluating the type of preventive and curative services which developed during the twentieth century, significant lessons from the past emerge. Foremost among these is the difficulty of legislating behaviour. Of equal importance is the role of catalytic events such as the two world wars in modifying perceptions of the appropriate role of the central government in health care policy. But the most interesting phenomenon is the way in which voluntary groups and local health departments pioneer health education and service activities which gradually become part of public policy. This dependence on evolution rather than executive federalism is typical of many aspects of Canadian life and clearly illustrates the importance of understanding the social context in which policy is being made and implemented.

Shaping attitudes and values, 1760-1867

After the British victory in the Seven Year's War, pacification of the Quebeçois was a key component of imperial policy. In 1773, when a new disease which bore a startling resemblance to syphilis appeared up river from Quebec City at Baie St. Paul, Governor Guy Carleton and his successor, Governor Frederick Haldimand, first sent medical aid and then appointed a commission to investigate the source and spread of the disease which attacked nearly 5,800 men, women and children by the end of the American Revolution. ${ }^{1}$ For the military, STDs would continue to be a source of anxiety throughout the nineteenth century. Naval authorities in Halifax tried unsuccessfully to have Britain's 1864 Contagious Diseases Act applied to Nova Scotia since they argued local prostitutes spread STDs among their personnel. ${ }^{2}$ Similar views influenced both civilian and military leaders in the United Canadas and from 1865 to 1870 , the British legislation was applied to Ontario and Quebec. In Toronto, the General Hospital created a lock ward for women infected with STDs and in Montreal and other Quebec cities magistrates could order medical inspection of arrested prostitutes. ${ }^{3}$ The lack of public outcry in comparison to Great Britain indicates not only the moral stigma attached to these diseases but also the underlying belief that STDs were a health hazard for marginalised or deviant citizens.

War and apprehended war provided specific opportunities for government involvement in STD control. Peacetime, however, was devoted to the pursuit of economic growth and population expansion. Between 1815 and 1850, nearly three million British immigrants arrived in British North America. The newcomers found a strongly religious society beset with interdenominational rivalries and sectarian conflict but united behind a strict moral code. 
By the 1860s, British North American politicians were engaged in defining the political structure of a new nation. Health matters were of secondary interest. Indeed, section 91 of the British North America Act of 1867 which outlines the federal government's responsibilities clearly demonstrates the politicians' belief that centrally-directed economic growth was the key to political stability. The only health-connected duties given to the central administration were collection of census and statistics and control of immigration and maritime quarantine. In section 92, the founding provinces, Ontario, Quebec, New Brunswick and Nova Scotia, were assigned the task of supporting hospitals, charities, asylums and eleemosynary institutions. Most of these were run by religious organisations or voluntary lay groups with some financial assistance from municipalities. For a small, predominantly rural population of 3.5 million who believed that health care was a personal or family responsibility, this division was understandable.

\section{Politics and priorities, 1867-1914}

During the 1870 s most provinces passed permissive public health legislation to control infectious diseases. Although asylum superintendents and some practitioners were starting to point out the costs and effects of STDs, these ailments were not included in the legislation. ${ }^{4}$ As Canada industrialised, cities and provinces began to create a public health bureaucracy whose activities provided the foundation for intervention in personal health matters. ${ }^{5}$ But both the Macdonald and Laurier administrations rejected the Canadian Medical Association's (CMA) recommendation that a national health department be created to co-ordinate public health measures on the grounds that this was a provincial duty.

By the beginning of the twentieth century when mortality rates from typhoid and other communicable diseases had begun to decline, local health officers shifted attention to maternal and infant mortality, health education and the needs of immigrants. From 1896 to 1913, Canada's second great wave of immigration helped its population expand to 8.5 million, contributed to western settlement and resulted in the creation of two new provinces, Alberta and Saskatchewan, for a total of nine in 1905. Although British immigrants predominated, public attention focused on non-English-speaking immigrants and ethnic minorities. Part of the anxiety about Canadian society's ability to integrate the latter arose from fear that they were more prolific than the native born, especially the middle classes who were evidently restricting their fertility. The first Canadian campaign against STDs had its origins in prewar reform activities which highlighted growing concern about "race purity" and "race suicide". 6

In fact, the groundwork for this effort lay in nineteenth century perceptions of male and female roles and human sexuality. The Victorian concept of the "proper sphere" was a middle class construct which linked women firmly to their roles as wives and mothers and limited their activity to the home. In contrast men were the breadwinners who participated in business and politics. These views were propounded by clergy, politicians, and opinion makers including members of the medical profession who often argued that female biology rendered women unfit for higher education or politics. ${ }^{7}$ This reductionist view extended to human sexuality. Women were seen as weak, passive and lacking sexual drive while men were just the opposite. As a result, the prevailing "double standard" which expected men to be sexually experienced prior to marriage and women to remain chaste was held up as the moral standard of the society. The "loose women" who assisted men in their pursuit of sexual experience were not only seen as the reservoir of STD infection but also as social pariahs. Only when the medical profession began to see frequent instances of congenital syphilis and gonorrhoea did reformers' concern about "innocent victims" lead to questions about social stereotypes and behaviour patterns. ${ }^{8}$

The exhortations of their ministers and priests, teachers and doctors defined acceptable public behaviour because Canadian society had a deeply-entrenched deference for authority. Since STDs were viewed as "the leprosy of lust" and "the wages of sin," the stigma of suffering from them was immense. Victims turned to home remedies, patent medicines and quacks because of the shame. Fear of exposure and the pain and costs associated with treatment meant that only the affluent and the poor were likely to receive medical aid. Doctors generally shared their society's inhibitions and values and were warned by contemporary textbooks to display great discretion, especially when treating married couples. Not until the American and French campaigns against STDs started after 1900 would Canadian reformers feel able to transgress the unwritten rules governing public discourse and actually open the question to public scrutiny. ${ }^{9}$ The medical and scientific discoveries of that decade and the outbreak of World War I provided an unrivalled opportunity to develop and direct a campaign against STDs.

Developing Canadian STD policy, 1914-1919

When the First World War began in August 1914, few people would have predicted the changes which it produced for Canadian society. The Borden government moved immediately to mobilise both the army and the population as Canada committed itself to the Allied cause. Mobilisation included the passage of the War Measures Act which effectively gave the federal government the power to control the lives of all Canadians including the provincial governments. The war therefore was an anomaly in the evolution of Canadian federalism because until this point power had been devolving to the provinces and now a strongly centralised operation was in place. ${ }^{10}$ 
Prior to the war, health reformers had argued that their efforts to combat various health problems were being frustrated by lack of national standards and sufficient funding for preventive work. Mass immunisation of Canadian forces proved their point as these preventive measures limited the amount of morbidity and mortality from traditional scourges such as smallpox and typhoid. ${ }^{11}$ The troops, however, quickly developed the highest rate of VD infections among the Allied personnel. By 1915 the somewhat dubious official statistics indicated that $28.5 \%$ of Canadian troops overseas were infected and receiving treatment for the diseases. Such "wastage" prompted firm measures from the Canadian authorities including weekly 'short arm' parade in front of the regimental medical officer, limited leaves, special hospital treatment and forfeited pay. When these failed to stem the spread of disease, graphic lectures and sermons stressing continence were added. ${ }^{12}$

Since the problem was not confined to the Canadian recruits, politicians and commanders from Canada, Australia and New Zealand united to press the British government to control prostitution. When this failed, the Dominions set up "blue light depots" where troops returning from leave could receive early treatment by washing their genitalia and applying calomel ointment These ad hoc measures demonstrated the limits which prevailing attitudes and values such as prohibiting the distribution of condoms to men going on leave imposed on policy development. In spite of its contradictions between rhetoric and action, the overseas experience became the foundation for government policy in the postwar period.

\section{Reform or reaction on the home front, 1914-1919}

On the home front, military and civilian authorities gradually stopped bickering over whether servicemen were infected prior to leaving Canada and turned their attention to developing policy which reflected the most successful components of existing public health work and the lessons learned during the war. For most, this meant a two-pronged attack on STDs using health education to prevent the spread of the disease and government-funded treatment to cure sufferers. The 1916 report of the British Royal Commission on Venereal Diseases and the revelation that $12-13 \%$ of the public ward patients attending Toronto General Hospital had positive Wassermann tests prompted the Ontario government to appoint its own one-man Royal Commission on Venereal Diseases and Feeblemindedness in 1917. Mr. Justice Hodgins mixed Victorian morality with twentieth century progressive concepts of national efficiency through the use of experts in his recommendation for restrictive anti-VD legislation at the provincial level and a national health department to co-ordinate an all-out attack on the problem. ${ }^{13}$

In 1918 Alberta, Ontario and
Saskatchewan passed legislation copied from Western Australia's 1915 act which made syphilis, gonorrhoea and chancroid the targets of government intervention for the first time. Individuals infected with these diseases were expected to seek professional medical treatment and to be cared for in provinciallyfunded hospitals. People charged with Criminal Code offenses such as prostitution or vagrancy could be tested for STDs. No one except the provincial government or its agent was allowed to provide educational literature, a provision aimed directly at patent medicine vendors and quacks. And anyone employed by a local or provincial health department to deal with STD clients had to maintain absolute secrecy or forfeit the position. To ensure that these requirements were carried out, most provincial health departments prepared lengthy regulations outlining preferred modes of treatment and created the bureaucratic structure necessary to ensure eradication of these diseases. ${ }^{14}$ With the exception of Prince Edward Island which did not pass anti-VD legislation until 1929, all of the remaining provinces passed similar laws in 1919 and 1920 , creating the infrastructure for a sustained attack on these diseases.

Provincial health authorities and the lay and medical activists who had united to form the Canadian National Committee for the Control of Venereal Disease (CNCCVD) in 1917 continued to press the Borden government to set up a federal health department. In February 1919 at a Dominion-provincial conference on health matters, New Brunswick and Manitoba moved the motion in favour of a federal department, Ontario and Saskatchewan moved a motion calling for federal financing of VD clinics similar to the arrangements made in Britain, and Ontario's Chief Medical Officer, J.W.S. McCullough, and Dr. Gordon Bates, the CNCCVD director, presented a set of guidelines for VD clinics based on the Ontario experience. ${ }^{15} \mathrm{All}$ of these recommendations were accepted. During the House of Commons debate on the bill to create a national health department, Members of Parliament were reminded that Canada had lost 60,000 killed and had 173,000 wounded and disabled in a force of 620,000 . As well, the influenza pandemic of 1918-19 had claimed an additional 50,000 young adults. To ensure that Canada became a home "fit for heroes" and their children, a federal health department with funds and a strong commitment to preventive work began operation in the summer of 1919. One of its ten divisions was devoted solely to the control and prevention of STDs in large part because of the experts' and politicians' perception that this was a national problem requiring federal intervention to resolve.

Education and treatment, 1919-1939

The anti-VD campaign that emerged during the 1920 s reflected wartime lessons and ultimately became a prototype for many of Canada's current cost-shared programs. The federal staff divided the annual appropriation 
of $\$ 200,000$ into funds for education and treatment. The bulk of the money was distributed on a per capita basis provided that the provinces met the federal criteria which included free clinics staffed by specialists, free hospital accommodation, free diagnostic services from provincial laboratories, "efficient treatment". of people in provincial jails, and a provincial VD division staffed by a specialist who would administer the program and direct health education efforts. If all these criteria and equivalent provincial funding were available, then the federal department would pay the full amount of the grant. ${ }^{16}$

Most provinces experienced little difficulty in hiring specialists as a few medical veterans had been convinced of the effectiveness of public health measures during their service with the Canadian Army Medical Corps and were willing to work as public servants. ${ }^{17}$ As they continued to modernise, Canadian hospitals sought further funding from provincial authorities so they swallowed their lingering distaste for treating STD cases and set aside specific beds in their wards as well as creating outpatient clinics. Provincial laboratory directors welcomed the opportunity to expand their activities and were assiduous in keeping up with the changing tests which European and American researchers introduced to limit the number of false positives which standard Wassermanns seemed to produce. ${ }^{18}$ Throughout the $1920 \mathrm{~s}$, most provinces created treatment facilities attached to correctional institutions and this contributed to a steady decline in STDs among professional prostitutes by the 1930 s. ${ }^{19}$

In theory, there should have been a marked decline in Canadian STD rates as a result of the organisation which produced 54 clinics by 1922 and 102 nationwide by 1932 . In reality, factors which the experts had not considered intervened to limit the impact of their work. Most provincial divisions quickly off-loaded their duties on local health departments and local hospitals. In Ontario, organised public health activists tried to make STDs part of the communicable disease control system but found that the social stigma influenced both doctors and patients to the extent that the diseases were rarely reported and treatment was often aborted as soon as the patient felt better. ${ }^{20}$ To combat this, the Ontario Health Department encouraged municipalities to send their public health nurses to Toronto where they trained with the experienced staff of the city's VD division for three months. These women were given an opportunity to see contact tracing and clinic service in a variety of social and ethnic milieux. ${ }^{21}$ Clearly the approach which had worked for other communicable diseases was less effective because general practitioners seem to have mistrusted the discretion of health department staff, to have preferred to treat patients in their offices and to have believed that reporting the disease by patient name was an intrusion into the doctor-patient relationship. ${ }^{22}$ As well, clinicians themselves believed their work was undervalued by their medical colleagues because it was not a prestigious specialty like surgery and viewed sceptically by the public which feared the lengthy and painful treatment which was standard practice for these diseases. $^{23}$

Overcoming the stigma associated with the diseases was another challenge which faced health administrators. This task had been delegated to the CNCCVD since no government wished to risk public disapproval. Drawing on the British and American campaign models, Bates and his supporters used modern health education techniques to educate Canadians about the dangers of STDs. Beginning with lectures, films, pamphlets, travelling exhibits and ultimately movies, the CNCCVD and its successor organisations, the Canadian Social Hygiene Council (1926-1936) and the Health League of Canada (1936-1981) "lifted the veil of secrecy" which surrounded STDs. ${ }^{24}$ The message which Bates and his staff delivered was tempered by the realisation that contemporary moral values had to be respected in spite of the fact that Bates was most critical of the "double standard" and the economic circumstances which in his opinion prevented early marriage. ${ }^{25}$ The rise of Freudian psychology challenged Victorian stereotypes of human sexuality but the strongly moralistic tone of STD educational material and gender-separated audiences remained in deference to Canadian conservatism.

During the mid-1920s, the public lost interest in the crusade against STDs. As conditions returned to "normal", politicians also began to question federal spending on a provincial matter and beginning in 1926, the King Liberals cut back on VD appropriations. Although the provinces had been told that this would occur after five years of full funding, the ministers of health still expressed shock at the loss of funds. Their protests were echoed by the CSHC, STD clinicians and opposition MPs but in 1932 the Bennett Conservatives eliminated the appropriations entirely. ${ }^{26}$ In response, the provinces consolidated their clinics and deemphasised health education.

The CSHC was also denied federal funds and it now turned to the public and other levels of government for support. The money raised financed an internationally acclaimed movie, "Damaged Lives." The voluntary group also sponsored VD surveys of Toronto in 1929, 1931, 1937 and 1943 and of Manitoba in 1930 and Ottawa in 1937. The limited data gathered during the 1930 s suggested that clinic use had increased while the incidence of new cases declined in spite of predictions that tertiary syphilis cases would be appearing as a result of the Great War. ${ }^{27}$ Federal statistics were based on reports from Ontario and Nova Scotia despite continuing efforts to standardize reporting and bureaucratise medicine.

Although such developments seemed to prove the effectiveness of federally-funded programs, the Canadian government's refusal to deficit finance until 1938 meant that health 
costs.were a significant problem for provinces and individuals during the dirty thirties. As a result, the medical profession and the Cooperative Commonwealth Federation, a new left-wing party, began to agitate for a national system of health insurance. ${ }^{28}$ In 1936-37, British Columbia not only designed the first provincial health insurance scheme but also reorganised its STD work to deal with the influx of young single males seeking work. The King government finally responded to increasing provincial and voluntary group pressure from the CMA, the Canadian Public Health Association and the National Council of Women and in 1938 introduced a $\$ 50,000$ grant to cover the cost of purchasing arsenicals for distribution by the provinces to practitioners who treated the indigent. ${ }^{29}$ The discovery of the sulpha drugs and their use in the treatment of gonorrhoea quickly changed the length of treatment and contributed to the hope that STDs might be controlled. But fundamental issues remained. Had the education campaigns altered Canadians' understanding of the causes and consequences of these diseases? Was the apparent decline in STD rates real or merely an artifact of limited reporting?

Victory or mirage?: STD policy, 1939-1964

When the Second World War began in September 1939, health authorities turned to the past for policy guidelines. The Ontario government convened a conference on October 10, 1939 to discuss the most recent advances in diagnosis and treatment of STDs and Dr. J.J. Heagerty, the former director of the federal VD control division and current director of the public health division, spoke to his colleagues about the techniques and tactics used in the First World War. Many of these such as the "blue light depots," (except that the lights were now green) were reintroduced for service personnel. Vivid posters reminded the military that VINO + VENUS $=$ VEEDEE but a more realistic appreciation of servicemen's behaviour also meant that thousands of condoms and prophylactic packages were distributed prior to leaves. The impact of this strategy was apparent because in contrast to the preceding conflict which had produced an STD rate of 220 per 1,000, the Second World War saw only 92 per 1,000 succumb..$^{30}$ As articles by Air Force medical staff indicate, the military used civilian methods of health education, patient treatment and contact tracing but found as had their predecessors that "casual pick-ups" rather than prostitutes were the main source of infection. ${ }^{31}$ This knowledge, however, did not lead them to change their health education tactics which continued to encourage abstinence.

The recruitment of women posed a challenge since they too acquired infections. Unlike their male peers, they had been given little specific advice on how to avoid STDs since Victorian gender barriers still influenced senior commanders. When the armed services introduced penicillin in 1943, its use was restricted to personnel overseas and male "sulphonamide-resistant hospitalised cases of gonorrhea." Only after supplies of the drug increased was it used to treat female personnel starting in June $1944 .{ }^{32}$

On the home front, the Health League leapt into action demanding the re-establishment of federal funding and direction and organizing Social Hygiene Days beginning in 1943 to raise public awareness of the economic and personal costs of these diseases, especially among teenagers. ${ }^{33}$ In 1943 the federal government not only re-created its VD division but also began serious postwar reconstruction planning including the development of a proposal for a national system of health insurance. The comprehensive plan was presented to the provinces on 6 August 1945, signalling the federal government's commitment to creating a social welfare state. ${ }^{34}$ The more affluent provinces such as Ontario and British Columbia and those who feared the loss of power such as Quebec united to reject it. Twenty further years of negotiation would be required before Canada obtained its medicare system. Out of the ruins of the health initiative, the newly created Department of National Health (1944) developed a series of health grants including funding for VD control programs. This was fortunate as Canada experienced its highest incidence of reported cases of VD in 1945 and 1946 when rates reached 336 and 338.3 per $100,000 .{ }^{35}$

From 1945 to 1949 , the Health League conducted a vigorous educational effort supported by the daily press, the medical profession and pharmacists. In response to this and wartime recommendations, the western provinces passed legislation requiring premarital blood tests and in 1948 Manitoba moved to translate its health literature into Cree to educate one group of aboriginals. ${ }^{36}$ In contrast to 1919 , health officials, clinicians and general practitioners were more optimistic that penicillin would provide the medical cure that would eliminate the moral and social dilemmas which accompanied the earlier campaign. As STD rates plummeted from 1949 to the mid-1950s, local and provincial health departments turned their attention to other more pressing problems. ${ }^{37}$

Old problems, new approaches: STDs, 1964-1992 By the end of the 1950s antibiotic-resistant strains of STDs were challenging everyone's faith in medical miracles. The impact of this development was compounded because in the 1960s the moral code which had underpinned Canadian society seemed to crumble as the baby boom generation discovered the joys of "free love" and vocal opposition to most forms of expertise and authority. Health departments responded either by using the provisions of existing legislation to ensure compliance or by adopting an epidemiological approach. In British Columbia, two high risk groups were identified: the gay community in Vancouver and single male resource workers in the interior. One worker was able 
to obtain the trust of Vancouver's STD sufferers and ensure that they received treatment while other fieldworkers were sent into the interior to provide clients with large doses of penicillin and its derivatives in an effort to control the spread of disease. ${ }^{38}$

By 1964 all health authorities were seriously alarmed by the rising rates of STDs and the CPHA convened a conference to discuss a national strategy. Interest in the project was derailed by the publication of the Royal Commission on Health Services and the political battles surrounding the drafting and passage of the Canada Medical Act in 1968. As part of the administrative reorganisation, the federal VD division was made into a component of the Bureau of Communicable Disease Epidemiology. This resulted in greater attention to statistical measures but less active involvement by the senior government.

By 1971 all of the provinces had agreed to join the national medicare scheme but questions were already being raised about its costs and effectiveness. In 1974 the Minister of Health, Marc Lalonde, published $A$ New Perspective on Health for Canadians in which he argued that government spending on curative measures and institutions was not an appropriate measure of a nation's health. He identified four variables including the environment, lifestyle, human biology and the health care system which affected each citizen's health. For Lalonde and his Conservative successors, health promotion through behaviour modification not only responded to growing public demand for a stake in defining health care policy but also offered cost savings while shifting the curative burden to the provinces.

STDs were described as lifestyle problems that could be alleviated by better sex education for young people and greater recognition of the "self-imposed" risk by the sexually adventurous. Critics argued that Lalonde was engaged in "blaming the victim" and pointed out how difficult it was to transform human behaviour. ${ }^{39}$ Discussions at national and international STD conferences during the late 1970s and early 1980s indicated a growing split between doctors and other health care professionals about the best strategies to use to lower Canada's national STD rate from its postwar peak of 229 per 100000 in 1977. The former wanted further epidemiological and clinical studies while the latter argued in favour of funding community health promotion efforts and analysing the weaknesses of current health education activities. ${ }^{40}$

In fact, significant redefinition of policy was underway. Studies of reporting practices among physicians in Manitoba, Prince Edward Island, Newfoundland and New Brunswick indicated that most doctors believed that they reported STD cases more frequently than they did and that many objected to the lack of follow-up and cumbersome reporting procedures. ${ }^{41}$ Analyses of patient records in Winnipeg demonstrated that poorly educated, underemployed or unemployed men and women, often aboriginals, were more likely to be repeat patients than those who had marginally better backgrounds and some family attachments. ${ }^{42}$ Sociological studies of this nature helped to re-orient the health education message from society at large to specific target groups including homosexuals who were disproportionately represented in STD statistics for Montreal, Toronto and Vancouver. Although public health staff had long been aware of this group, the Canadian Criminal Code was not amended to permit sexual activity between consenting adults of the same sex until 1969. Public acceptance of this alternate lifestyle was significantly slower to occur as STDs were still predominantly associated with marginalized groups such as street kids, prostitutes, drug users, aboriginals and gays.

During the 1970s, "new" STDs such as NGU, PID, chlamydial infection and herpes become the subject of scientific study and public concern as infertility and suffering increased. Federal epidemiologists noted that women in the 15 to 29 age group were prone to PID as a result of undiagnosed or untreated gonorrhoea and that this had contributed to an increase in ectopic pregnancies between 1971 and 1978. When the costs of hospital care for this condition was added to the \$76-100 million spent annually to treat the estimated 600000 cases of STDs in the Canadian population of 25 million, it brought health expenditures to roughly $\$ 200$ million. $^{43}$ Unlike Great Britain, Canada had never developed venereology as a medical specialty. Medical training in this field was usually limited to classroom instruction and few physicians were comfortable inquiring into a patient's sexual practices. As well, the treatment that they provided to $70-80 \%$ of STD patients varied in quality and thoroughness as did their contact tracing and reporting. ${ }^{44}$ For health authorities changes to both medical school curricula and family physician's practice habits were essential.

The catalyst for change in the 1980 s was the appearance of AIDS. Unlike the other STDs, AIDS kills. Coming on the heels of a decade in which medicine lost much of its mystique and authority and appearing first in the gay community this STD challenged all levels of government, health care personnel and the public to rethink accepted approaches to discovering, treating and preventing disease. Quickly organising local groups, AIDS activists publicised their cause to gain support and funding. Like their predecessors prior to 1914 , they found municipal and provincial governments more responsive than federal authorities. In contrast to earlier efforts, they developed successful education strategies that used humour and graphic language and illustrations to change their peers' behaviour. Their activism led most provinces to repeal the early twentieth century anti-VD legislation and to include STDs under public health laws. Only gradually have the provinces moved to eliminate nominal report- 
ing and to consider adopting self-referral for contacts. ${ }^{45}$

The impact of the AIDS epidemic in conjunction with the revelations of the extent of sexual abuse of children by a 1984 Royal Commission prompted the federal government to develop new Canadian Guidelines for the Diagnosis and Management of STDs, published in 1989. This material updates previous manuals and illustrates how doctors are increasingly being required to integrate medicine and community service. Canadian medical schools are now devoting far greater attention to STDs and the doctor's sociolegal responsibilities. In 1990 Canada's Minister of Health, Perrin Beatty, finally presented his government's white paper on AIDS in which he outlined current understanding of the disease, provided examples of community action, and set an agenda for the nineties which included "education and prevention, research and care, treatment and support." All of these actions explicitly or implicitly draw on the history of past efforts to control and prevent STDs.

\section{Conclusion}

What lessons does this brief overview offer to modern health administrators? First the humbling realisation that medicine has yet to unlock the secrets of STDs. Without a vaccine or other equally effective preventive measure, only prevention and treatment are viable options. Prevention has evolved from gender stereotyped exhortations to moral conduct to explicit advertisements and educational materials aimed directly at high risk groups. Although the gay community has altered its behaviour, many teenagers and sexually active adults have not. Promoting healthy sexual practices must continue to rank high on the agenda of health agencies and voluntary groups but given Canada's multicultural composition, discretion and sensitivity must inform all educational efforts.

The other significant change is broadening the range of policy makers. The first generation of STD activists were middle class professionals and women's groups. They assumed that their faith in human perfectibility was widely shared and that their expertise legitimised their intervention. Today formerly marginalised groups are part of the process. This broadening out slows the development and implementation of policy but ultimately makes it more acceptable to its consumers and its providers.

Within the political arena, interest in STDs has waxed and waned as rates rose and fell. Canadian politicians and the public responded to the demands of medical experts and health bureaucrats during crises such as the World Wars but only provincial and local health departments maintained sustained treatment services. The decision of the Mulroney government to support health promotion, announced in Achieving Health for All: A Framework for Health Promotion in 1986 indicated a shift away from the scientific research model which had dominated the health care sector to that time. As in the past, most innovations such as needle exchanges in Vancouver, condoms in high school vending machines in Ontario and condoms for prisoners in Quebec jails are being introduced by other levels of government after sustained interest group agitation. As such programs diffuse across provincial boundaries through professional and grassroots interaction and become politically acceptable, they win recognition from federal politicians and administrators. Thinking globally but acting locally should assist contemporary STD activists in their ongoing efforts to develop a national STD policy.

1 Leblond S. La mal de la Baie: était-ce la syphilis? Can Med Assoc F 1977;116:1284-88, 1290.

2 Fingard J. The Dark Side of Life in Victorian Halifax, Porter's Lake, Nova Scotia, Pottersfield Press, 1991.

3 Toronto General Hospital. Trustee's Minutes March 1866 December 1879, March 5, 1866. Pelletier E. Public Health in Quebec. In: Defries RD ed. The Development of Public Health in Canada, Toronto, Canadian Public Health Association, 1940, 14-23.

4 Mitchinson W. Reasons for Committal to a Mid Nineteenth Century Ontario Insane Asylum: The Case of Toronto. In: Mitchinson W, McGinnis JD, eds. Essays in the History of Canadian Medicine, Toronto, Essays in the History of Canadian Med

5 MacDougall H. Public Health and the 'Sanitary Idea' in Toronto, 1866-1890. In: Mitchison W, McGinnis JD eds. Essays in the History of Canadian Medicine, Toronto McClellan \& Stewart 1988, 62-87.

6 McLaren A, McLaren AT. The Bedroom and the State: The Changing Practices and Politics of Contraception and Birth Control in Canada, 1880-1980, Toronto, McClelland \& Stewart, 1986, 1-53.

7 Mitchinson W. The Nature of Their Bodies: Women and Their Doctors in Victorian Canada, Toronto, University of Toronto Press, 1991, 48-76.

8 Cassel J. The Secret Plague: Venereal Disease in Canada 1838-1939, Toronto, University of Toronto Press, $1987,71-100$

9 Cassel J. The Secret Plague: Venereal Disease in Canada 1838-1939, Toronto, University of Toronto Press, 1987, 101-21.

10 Brown RC, Cook R. Canada 1896-1921: A Nation Transformed, Toronto, McClelland \& Stewart, 1974

11 Morton D. Military Medicine and State Medicine: Historical Notes on the Canadian Army Medical Corps in the First World War 1914-1919. In: Naylor, CD, ed., Canadian Health Care and the State: $A$ Century of Evolution, Montreal \& Kingston, McGill-Queen's University Press, 1992, 38-66.

12 Cassel J. The Secret Plague: Venereal Disease in Canada 1838-1939, Toronto, University of Toronto Press, 1838-1939, $1987,122-44$.

13 Ontario, Legislative Assembly, Sessional Papers, 1918, Vol 50, part 9, no. 57. Interim Report on Venereal Diseases and Copy of an Act for the Prevention of Venereal Disease.

14 Ontario, Statutes, An Act for the Prevention of Venereal Disease, 8 Geo. V, Chapter 42, 1918

15 Cassel J. The Secret Plague: Venereal Disease in Canada 1838-1939, Toronto, University of Toronto Press, $1987,168-9$

16 Cassel J. The Secret Plague: Venereal Disease in Canada 1838-1939, Toronto, University of Toronto Press, $1987,169$.

17 Morton D. In: Naylor, Canadian Health Care and the State, 47-8.

$18 \mathrm{MacNabb}$ AL, Matthews G. Interpretation of Serodiagnostic Procedures in Syphilis. Canadian Public Health fournal 1939;40:571-9.

19 Parney FS. The Venereal Disease Situation in Canada Canadian Public Health fournal. 1932;23:553-561.

20 Heagerty J. Venereal Disease Situation in Canada. Public Health fournal, (PHO) 1922;13:485-96. Pequegnat LA The General Practitioner and Venereal Disease Control in Urban Areas. Canadian Public Health fournal 1941;32:18-23.

21 Brown FE. Public Health Nurses in Venereal Disease Clinics. Canadian Public Health fournal 1923;14:76-81.

22 Brown FE. The Social Aspects of Venereal Disese Control. Canadian Public Health fournal 1924:15:72-82. Control. Canadian Public Health fournal 1924;15:72-82. Desloges AH. Venereal Disease Control in the Province of 433-41. McGinnis JD. From Salvarsan to Penicillin: 
Medical Science and VD Control in Canada. In Mitchinson W, McGinnis JD, eds, Essays in the History of Canadian Medicine, 126-47.

24 Cassel J. The Secret Plague: Venereal Disease in Canada 1838-1939, Toronto, University of Toronto Press, $1987,206-45$.

25 Bates G. The Relation of the Canadian National Council for Combating Venereal Diseases to the Programme of Venereal Disease Control. Canadian Public Health fournal, 1921;12:156-162. As late as 1973, two years before his death, Bates was still editorializing in Health, the League's bi-monthly magazine about the moral and social aspects of VD.

26 McGinnis JPD. From Health to Welfare: Federal Government Policies regarding Standards of Public Health for Canadians, 1919-1945, $\mathrm{PhD}$ dissertation University of Alberta, 1980, 102-4.

27 A Venereal Disease Survey in Manitoba. Canadian Public Health fournal, 1931;22:189-93. Clarke JT. A Survey of the Incidence of Venereal Diseases in Ottawa Canada November 1937. Canadian Public Health foumal, 1938;28:213-5. Bates G. A Survey of the Incidence of Venereal Diseases in Toronto in 1943. Canadian Public Health fournal, 1944;35:234-40.

28 Naylor CD. Private Practice, Public Payment: Canadian Medicine and the Politics of Health Insurance 1911-1966. Montreal \& Kingston, McGill-Queen's University Press, 1986.

29 Cassel J. Making Canada Safe for Sex: Government and the Problem of Sexually Transmitted Disease in the Twentieth Century. In: Naylor, ed., Canadian Health Care and the State, 141-92.

30 Peart AFW. The venereal disease problem in Canada. Canadian Public Health fournal, 1953;44:160-6.

31 Tice JW, Sellers AH, Anderson RM, Nichols W. Some Observations on Venereal-Disease Control in the Royal Canadian Air Force. Canadian Public Health fournal, 1946;37:43-56.

32 Pierson RR. The Double Bind of the Double Standard: VD Control and the CWAC in World War II. Canadian VD Control and the CWAC in Wor

33 Bates G. Venereal Disease and the Worker. Health, 1942;9:8,29-30. Williams DH. A 6 Point Attack Against Venereal Disease. Health, 1943;10:6-7, 27 , 29-30. Smith C. Teen Age Tragedy. Health, 1943;10:10-11, 27. Smith C. Social Hygiene Day: The Opening Barrage. Health, 1943-44;11:13,29-30. Lichstein J. Pharmacy Fights VD. Health, 1945;12:14.

34 Canada. Bureau of Statistics. Reprint of Health Reference Book for Dominion-Provincial Conference on Reconstruction. August, 1945, 26-30.
35 Canada. Minister of National Health and Welfare. Sexually Transmitted Disease in Canada 1976. Ottawa $1977,38,40$

36 Cassel J. Making Canada Safe for Sex, 163. Manitoba. Manitoba Health Survey Report. Winnipeg, Queen's Printer, 1953,25.

37 Peart AW. The venereal disease problem in Canada. Canadian Public Health fournal, 1953;44:160-6.

38 Kennedy HK. The control of venereal disease in British Columbia. Canadian Public Health foumal, 1969;60: Colum.

39 MacDougall H. Activists and Advocates: Toronto's Health Department, 1883-1983, Toronto, Dundurn Press, $1990,220-224$

40 LeBourdais E. VD apathy among doctors. Dimensions in Health Service, 1978;55:15. White FMM. Sexually transmitted diseases: issues and priorities. Can Med Assoc F, 1983;128:1178-1182. Sacks SL, Bowie WR Stayner M. Education and Public Awareness of Sexually Transmitted Diseases. Canadian Public Health Fournal, 1983;74:176-8.

41 Scatliff JNR. Survey of venereal disease treated by Manitoba physicians in 1972. Can Med Assoc $\mathscr{F}$ 1974;110:179-82. Scatliff JNR. Medical Reporting of 1974;110:179-82. Scatiff JNR. Medical Reporting of Public Health fournal, 1982;73:131-3. Hockin JC. Public Health Fournal, 1982;73:131-3. Hockin JC. A Survey of Sexually Transmitted Diseases Diagnosed fournal, 1985;76:30-2. Sweet L, Hockin JC, Jessamin AG, Stewart WR, Walters DJ. A Survey of Sexually Transmitted Diseases Diagnosed by Physicians in New Brunswick and Prince Edward Island. Canadian Public Health foumal, 1987;78:91-4.

42 Lundin RS, Wright MW, Scatliff JNR. Behavioural and social characteristics of the patient with repeated venereal disease and his effect on statistics on venereal disease. Br ¥ Venereal Dis, 1977;53:140-4.

43 Jessamine AG, Mathias R, Sutherland R. Epidemiology and Control of Sexually Transmitted Diseases. and Control of Sexually Transmitted

44 Robert Y, Tobert J. Un Autre Regard Sur Un Vieux Sujet Ou Les Avatars De La Lutte Antivénérienne. L'Union Médicale Du Canada, 1978;107:728-31. Catterall RD. Sexually transmitted diseases in Ontario. $B r \mathcal{F}$ Venereal Dis, 1979;55:300-3. Stamm WE, Kaetz S, Holmes KK Clinical Training in Venereology in the United States and Canada. $\mathcal{F A M} A$ 1982;248:2020-4.

45 Cassel J. Making Canada Safe for Sex: Government and the Problem of Sexually Transmitted Disease in the Twentieth Century. In Naylor, ed., Canadian Health Care and the State, 141-78. 